\title{
PERKERETAAPIAN MASA KOLONIAL BELANDA DI WILAYAH INDRAMAYU: PEMETAAN JALUR DAN BUKTI TINGGALAN ARKEOLOGIS
}

\section{Train in Dutch Colonial Period in Indramayu Region: Mapping Routes and Train Heritage}

\author{
Revi Mainaki ${ }^{1 a}$, Iwan Hermawan ${ }^{2 b}$ \\ ${ }^{1}$ Universitas Siliwangi \\ Jl. Siliwangi no.24 Tasikmalaya, Indonesia \\ ${ }^{2}$ Balai Arkeologi Jawa Barat \\ Jl. Cinunuk Km.17, Kota Bandung, Indonesia \\ arevi.mainaki@unsil.ac.id \\ biwan1772@gmail.com
}

Naskah diterima: 27/09/2019; direvisi: 04/11-27/11/2019; disetujui: 28/11/2019

Publikasi ejurnal: 28/11/2019

\begin{abstract}
The development of railways in Indonesia is related to the exploration and exploitation of the Dutch Colonial Government. This mode of transportation is used for the transport of agricultural commodities so that a compilation of enforced planting politics is enforced. Indramayu is one of the areas on the island of North Java which is traversed by the construction of this route, so it has archaeological remains, everything related to trains or is called railways. This remains a fact and basis in colonial history. The difficulty of preserving the railroad relics in the Indramayu Region is difficult to find and approve. Through qualitative and exploratory methods, this study further discusses railways that have archaeological values on the track built by the Dutch colonial government, namely (1) the non-active Jatibarang - Indramayu railway line; (2) Jatibarang - Karangampel non-active train line; (3) Haurgeulis - Arjawinangun Lane which is an active route at this time. Data collected through literature studies, documentation studies, observations collected by interviews. The results showed some relics in this region which are found in several districts namely Jatibarang, Karangampel, Haurgeulis Districts and along the Jatibarang-Indramayu, Jatibarang-Karangampel and Jatibarang-Arjawinangun subdistricts. Also around the former station Kadokangabus Station, Terisi and Telagasari. Besides that, it was located in the center of Cimanuk economic activity during the colonial period.
\end{abstract}

Keyword: Mapping Routes, Train Heritage, Dutch Colonial Period.

Abstrak
Perkembangan kereta api di Indonesia, terkait dengan eksplorasi dan eksploitasi Pemerintah Kolonial Belanda. Mode transportasi ini digunakan untuk pengangkutan komoditas pertanian, sehingga menguat ketika diberlakukannya politik tanam paksa. Indramayu adalah salah satu wilayah di Utara Pulau Jawa yang dilalui oleh pembangunan jalur ini, sehingga memiliki tinggalan arkeologis, segala sesuatu yang berhubungan dengan kereta api atau disebut dengan perkretaapian. Tinggalan tersebut menjadi fakta dan dasar dalam mengidentifikasi sejarah masa kolonial. Kurangnya kesadaran pelestarian tinggalan perkretaapian di Wilayah Indramayu, membuatnya sulit dicari dan di identifikasi. Melalui pendekatan kualitatif dan metode eksploratif, penelitian ini mengidentifikasi tinggalan perkeretaapian yang memiliki nilai arkeologis di jalur yang dibangun pemerintah kolonial belanda yakni jalur (1) Jalur kereta api non aktif Jatibarang - Indramayu; (2) Jalur kereta api non aktif Jatibarang - Karangampel; (3) Jalur Haurgeulis - Arjawinangun yang merupakan jalur aktif saat ini. Data dikumpulkan melalui studi literatur, studi dokumentasi, observasi yang diperkuat oleh wawancara. Hasil penelitian menunjukan beberapa peninggalan di wilayah ini yang terdapat di beberapa kecamatan yakni Kecamatan Jatibarang, Karangampel, Haurgeulis serta di sepanjang jalur penelusuran Jatibarang-Indramayu, JatibarangKarangampel dan Jatibarang-Arjawinangun. Juga di sekitar bekas stasiun Stasiun Kadokangabus, Terisi dan Telagasari. Selain itu terdapat tinggalan di pusat aktivitas ekonomi Cimanuk pada masa kolonial.

Kata Kunci: Pemetaan Jalur, Tinggalan Perkeretaapian , Masa Kolonial Belanda. 


\section{PENDAHULUAN}

Perkembangan suatu wilayah wilayah tidak dapat lepas dari perkembangan mode transportasinya, mode transportasi yang dibuat oleh manusia selalu memperhitungkan efisiensi jarak, waktu dan kuantitas yang dapat diangkut.

Salah satu mode transportasi yang berkembang sejak masa Kolonial Belanda dengan efisiensinya adalah kereta api. Perkembangan mode transportasi kereta api terkait dengan eksplorasi dan eksploitasi sumberdaya alam yang dilakukan pemerintah kolonial di Indonesia. Indramayu merupakan salah satu yang tidak lepas dari pembangunan tersebut.

Segala sesuatu yang berkaitan dengan kereta api atau disebut dengan perkretaapian pada masa kolonial merupakan tinggalan arkeologis yang berharga, karena merupakan fakta sejarah yang melalui tinggalan tersebut kita dapat melakukan rekonstruksi serta identifikasi keterkaitan Wilayah Indramayu dengan wilayah lainnya yang ada di Pulau Jawa, kemudian dapat disimpulkan fungsi, peran dan potensi Wilayah Indramayu di masa kolonial, yang dapat dimanfaatkan sampai saat ini. Fase pembangunan rel yang terjadi dan gencar saat dilakukannya tanam paksa akan menunjukan fungsi transportasi dengan perkembangan wilayah dan komoditas khas Wilayah Indramayu itu sendiri. Kurangnya kesadaran akan upaya inventarisasi data dalam pelestarian tinggalan perkretaapian, khususnya di Wilayah Indramayu membuatnya tidak mudah untuk ditemukan dan diidentifikasi sehingga perlu penelitian terkait hal tersebut.

Jalur rel kereta api di Indramayu tidak lepas dari perkembangan Wilayah Cirebon sebagai kota pelabuhan dan kota perdagangan yang sudah dikenal sejak abad ke 16, hasil eksporasi dan eksploitasi sumberdaya alam beberapa wilayah di Pulau Jawa diangkut dan dibawa ke Pelabuhan Cirebon untuk selanjutnya diteruskan dan dibawa ke negaranya baik untuk konsumsi maupun untuk diperdagangkan secara internasional ke Malaka dengan komoditas beras yang paling terkenal dan dibawa ke Malaka. Pembangunan jalur rel kereta api semakin menguat ketika diberlakukannya politik tanam paksa (Hendro, 2014; Makkelo, 2017).

Indramayu merupakan salah satu wilayah di bagian Utara Pulau Jawa yang dilalui oleh jalur rel kereta api pemerintah kolonial, yang dibangun oleh Staatsspoorwegen (SS) yakni perusahaan Kereta api milik pemerintah Kolonial Belanda dengan jalur trem JatibarangIndramayu pada tahun 1912, jalur Jatibarang Karangampel tahun 1926 namun pada tahun 1932 jalur ini ditutup dan Jalur Haurgeulis Arjawinangun yang merupakan bagian dari jalur utama Jakarta - Cirebon yang dibangun SS dan mulai beroperasi pada tahun 1912 (Purwanto, 2008).

Saat ini jalur trem Jatibarang Indramayu serta Jatibarang - Karangampel di Wilayah Indramayu, merupakan jalur kereta api yang sudah tidak aktif dan berada pada wilayah kerja DAOP 3 Cirebon. Keberadaan jalur kereta api baik yang masih aktif, maupun yang sudah tidak digunakan merupakan bukti adanya hubungan atau keterkaitan antar wilayah dengan menggunakan mode transportasi massal, salah satu alasan terjadinya perkembangan wilayah adalah adanya peningkatan dan perkembangan transportasi publik (Anwar, 2017).

Eksploitasi dan eksplorasi pemerintah kolonial yang terkait dengan tanam paksa diantaranya adalah komoditas tebu, ditunjukan dengan adanya beberapa pabrik pengolahan tebu menjadi gula di sepanjang jalur rel kereta api Wilayah Cirebon dan Indramayu diantaranya pabrik gula Djatiwangi, Gempol, Khadipaten, Karangsoewoeng, Ardjawinangun, Paroengdjaja, Soerawinangun, Sindanglaoet, Nieuw Tersana, Leuweunggajah, Ketanggoengan West, Gist 
and Spiritus Fabriek Palimanan yang dibangun periode sebelum perang dunia II (Hasil wawancara humas pabrik gula).

Pembangunan mode transportasi kereta api di Wilayah Indramayu pada masa kolonial mampu membangkitkan berbagai sektor kehidupan masyarakat. Bagi pemerintah kolonial diuntungkan dengan adanya transportasi yang cepat dan murah untuk mengirim hasil produk perkebunan mereka ke pelabuhan. Bagi masyarakat umum, keberadaan transportasi kereta api memudahkan mereka mengirim dan memasarkan hasil pertanian dan kerajinan ke kota-kota lain yang dilalui jalur kereta api (Ramadhan, 2017). Selain untuk kepentingan ekonomi pembangunan perkeretaapian pada masa kolonial juga ditujukan untuk kepentingan pertahanan. Keberadaan kereta api akan memudahkan mobilitas pasukan dari satu tempat ke tempat lainnya (Ramadhan, 2017).

Tampak bahwa kereta api mempunyai peran besar dalam pengangkutan komoditas hasil pertanian, perkebunan, dan kehutanan pada masa Kolonial Belanda, khususnya di Wilayah Indramayu. Pada sisi lain, tumbuhnya industri pertanian dan perkebunan juga mendorong peningkatan aktivitas manusia antar ruang antar wilayah. Wilayah-wilayah tertentu di sepanjang jalur kereta api juga turut berkembang menjadi pusat-pusat aktivitas manusia dalam skala yang awalnya kecil dan terus berkembang. Pencarian dan penelitian transportasi pada masa Kolonial Belanda merupakan sesuatu yang menarik untuk diteliti lebih lanjut melalui tinggalan arkeologi berupa bangunan, jejak rel atau tinggalan lainnya sebagai bukti untuk menjelaskan secara ilmiah perkembangan transportasi kereta api terkait aktivitas ekonomi masa Kolonial Belanda (Pratikto, 2018; Pribadi, 2012).

Artikel ini menguraikan hasil penelitian eksplorasi dan identifikasi arkeologi berupa tinggalan perkeretaapian masa Kolonial Belanda di Wilayah
Indramayu yang kemudian disajikan dalam bentuk peta dan deskripsi sebagai hasil analisis dan penelitian eksplorasi yang dilakukan di Wilayah Cirebon.

\section{METODE PENELITIAN}

Penelitian ini dilakukan di Wilayah Indramayu, yakni sepanjang jalur rel kereta api peninggalan masa Kolonial Belanda baik yang sampai saat ini masih digunakan atau yang sudah tidak aktif. Penelusuran dan observasi dilakukan pada tiga jalur sisa peninggalan pemerintah Kolonial Belanda yakni (1) Jalur kereta api non aktif Jatibarang - Indramayu; (2) Jalur kereta api non aktif Jatibarang - Karangampel; (3) Jalur Haurgeulis - Arjawinangun yang merupakan jalur aktif saat ini.

Sesuai dengan permasalahan dan tujuan penelitian yakni melakukan eksplorasi dan penelusuran tinggalan perkeretaapian di Wilayah Indramayu, penelitian ini menggunakan pendekatan kualitatif berbasis keruangan yang berangkat dari fakta bukti tinggalan perkeretaapian pada masa Kolonial Belanda, melalui metode eksplorasi deskriptif. Secara induktif peneliti melakukan pengumpulan data awal dengan melakukan studi dokumentasi dari berbagai instansi terkait, kemudian diperkuat oleh studi literatur dari berbagai referensi ilmiah yang relevan (Balan \& Ionita, 2011; Mudjianto, 2018; Reiter, 2017).

Selanjutkan dilakukan observasi dengan survei eksplorasi berdasarkan data awal yang didapatkan untuk mendapatkan hasil konfirmasi keberadaan tinggalan perkeretaapian menjadi bukti ilmiah. Data hasil observasi direkam dengan menggunakan kamera dan Global Positioning Sistem. Tinggalan yang ditemukan di sepanjang jalur rel kereta api tersebut kemudian diukur dan direkonstruksi dalam bentuk gambar teknis, selain itu tinggalan juga diambil gambarnya dengan menggunakan kamera. 
Data yang telah dikumpulkan melalui studi observasi di lapangan berdasarkan data awal yang didapatkan kemudian dianalisis dengan berbasis pada Sistem Informasi Geografis (SIG) sehingga sebaran tinggalan perkeretaapian di Wilayah Indramayu dalam bentuk peta digital dan terlihat secara regional. Selanjutnya dapat dianalisis bekas jalur rel kereta api dengan semua fasilitasnya pada masa kolonial. Hasil rekonstruksi dapat dianalisis dan terlihat bagaimana pola serta posisi tinggalan tersebut. Peta yang didasarkan pada data hasil observasi kemudian dideskripsikan sebagai hasil penelitian dan ditarik kesimpulan bagaimana sebaran dan deskripsi tinggalan perkeretaapian di Wilayah Indramayu.

\section{HASIL DAN PEMBAHASAN}

\section{Kondisi Geografis Wilayah Indramayu sebagai Pengaruh Keberadaan Komoditas yang di Eksplorasi Pemerintah Kolonial Belanda.}

Secara geografis Kabupaten Indramayu terletak pada $107^{0} 52^{\prime}-108^{0} 36^{\prime}$ Bujur Timur dan $06^{0} 15^{\prime}-06^{0} 40^{\prime}$ Lintang Selatan. Sedangkan berdasarkan topografinya sebagian besar merupakan dataran atau daerah landai dengan kemiringan tanahnya rata-rata $0-2 \%$. Keadaan ini berpengaruh terhadap drainase, bila curah hujan cukup tinggi, maka di daerah-daerah tertentu akan terjadi genangan air.

Kabupaten Indramayu terletak di pesisir utara Pulau Jawa, yang melalui 11 kecamatan dengan 36 desa yang berbatasan langsung dengan laut dengan panjang garis pantai $147 \mathrm{Km}$. Letak Kabupaten Indramayu yang membentang sepanjang pesisir pantai utara P.Jawa membuat suhu udara di kabupaten ini cukup tinggi, yaitu berkisar antara $22,9^{\circ}-30^{\circ}$ Celcius. Sementara ratarata curah hujan sepanjang Tahun 2014 adalah sebesar $2.104 \mathrm{~mm}$ dengan jumlah hari hujan 103 hari. Adapun curah hujan tertinggi terjadi di Kecamatan Lohbener kurang lebih sebesar $2.756 \mathrm{~mm}$ dengan jumlah hari hujan tercatat 125 hari, sedang curah hujan terendah terjadi di Kecamatan Terisi kurang lebih sebesar $666 \mathrm{~mm}$ dengan jumlah hari hujan 52 hari (BPS, 2015).

\section{Perkembangan Jalur dan Fasilitas Rel Kereta Api.}

Jejak kereta api di Indramayu dapat dikelompokan menjadi dua kelompak jalur kereta api, yaitu Jalur aktif dan jalur non aktif. Jalur aktif di Indramayu, yaitu jalur Haurgeulis - Jatibarang - Stasiun Cirebon dan jalur non aktif, yaitu jalur trem Jatibatang -Indramayu dan jalur trem Jatibarang - Karangampel.

Pada bagian ini diuraikan Jejak atau tinggalan arkeologis perkeretaapian dan tinggalan non perkeretaapian di wilayah Kabupaten Indramayu, yaitu tinggalan pada jalur kereta api non aktif Jatibarang Indramayu, Jatibarang - Karangampel, dan pada jalur aktif Haurgeulis - Arjawinangun (lampiran 1).

\section{Tinggalan Perkeretaapian di Kecamatan Jatibarang, Indramayu.} Jatibarang adalah salah satu kecamatan di Indramayu yang dilalui oleh jalur kereta api Jakarta - Cirebon. Lokasinya yang strategis menjadikannya lebih ramai dibanding Indramayu selaku pusat pemerintahan (lampiran 2).

Hal ini dikarenakan selain dilalui oleh Jalur kereta api, juga dilalui oleh Jalan Raya Pantura yang menjadi penghubung kota-kota di pesisir utara Jawa.Stasiun Jatibarang sebelum dibangun rel ganda Cikampek - Cirebon memiliki fasilitas Gudang barang, Gudang Pupuk, tempat bongkar muat kendaaraan di sepur buntu, tempat bongkar muat hewan, dan Klinik Kesehatan.

Tinggalan Arkeologis berupa tinggalan perkeretaapian di Emplasemen Jatibarang (gambar 1A), adalah Bangunan Stasiun Jatibarang (gambar 1B), Rumah 

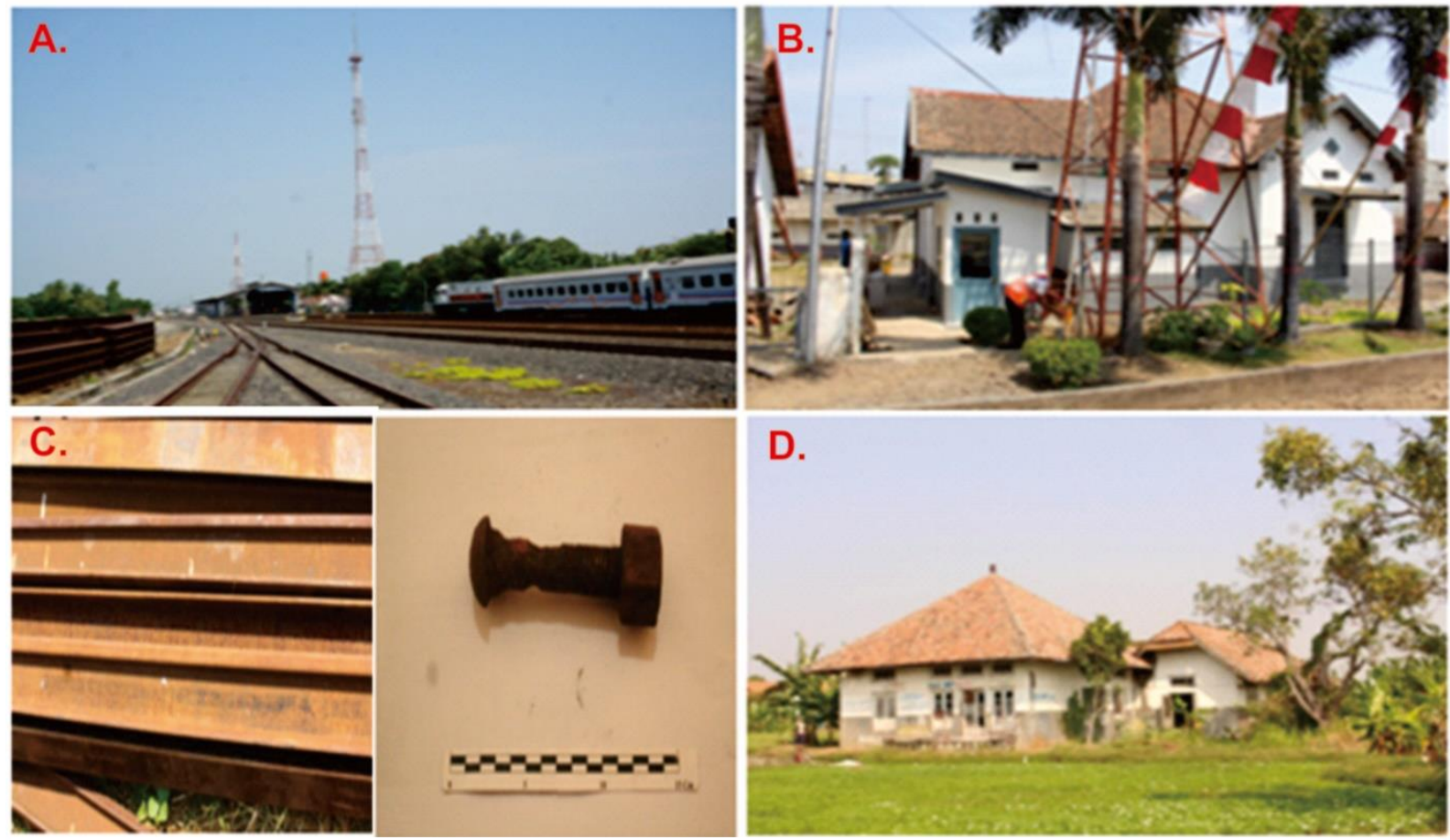

Gambar 1. Emplasemen Stasiun Jatibarang Indramayu (A). Rumah dinas pejabat Stasiun Jatibarang (B). Sisa depo lokomotif Stasiun Jatibarang (C). . Pabrik pengolahan beras di Stasiun Jatibarang (D) (Sumber: Balai Arkeologi Jawa Barat, Tahun 2018)

Dinas Pejabat Kereta Api, dan Temuan lepas, serta tinggalan arkeologis lainnya di luar tinggalan perkeretaapian. Stasiun Jatibarang berada pada Km. 179+120 dari arah Jakarta atau Km. 0 pada jalur Jatibarang - Indramayu dan Jatibarang - Karangampel, pada ketinggian 12 mdpl.

Bangunan stasiun berada di lingkungan Pasar lama Jatibarang di Jl. Mayor Sangun, Desa Jatibarang Kecamatan Jatibarang Kabupaten Indramayu pada koordinat 1080 18' 17.54" BT dan 060 28' 11.35" LS. Menurut informasi Bapak Agus, Staf bagian keuangan Stasiun Jatibarang dan merupakan pegawai senior di Stasiun Jatibarang, Emplasemen Stasiun Jatibarang sebelumnya merupakan emplasemen yang luas dengan 17 sepur serta dilengkapi Depo Lokomotif (gambar 1C). Selain itu juga terdapat kantor Jalan dan Jembatan, Kantor Polisi Khusus, Kantor PUK, Kantor Persinyalan, SSK, dan UUK. Komoditas perdagangan terbesar dari Indramayu adalah Beras. Guna menampung dan mengolah hasil produksi padi, di banyak lokasi didirikan penggilingan padi atau masyarakat setempat menyebutnya Pabrik Padi/Beras (Heleran/Huller).

Salah satu Penggilingan padi dibangun di Jatibarang tepi jalan raya Jatibarang - Indramayu atau Jalan Tentara Pelajar Jatibarang tidak jauh dari Stasiun Jatibarang, tepatnya di Kampung/Desa Kebalen Kecamatan Jatibarang pada koordinat $108^{0} 18^{\prime} 00,27^{\prime \prime}$ BT dan 06027'48,93" LS (gambar 1D). Komplek Penggilingan Padi terdiri dari Bangunan Administrasi, Lapangan Penjemuran, Gudang, dan bangunan Pabrik (penggilingan padi), serta jalur Lori/ Kereta pengangkut dari Gudang Pabrik ke Stasiun Jatibarang.

\section{Tinggalan Perkeretaapian di Jalur Jatibarang-Indramayu.}

Jalur Jatibarang - Indramayu merupakan jalur Trem dari Stasiun Jatibarang sampai ke Stasiun Indramayu di Paoman. Seperti telah diuraikan di atas, jalur 

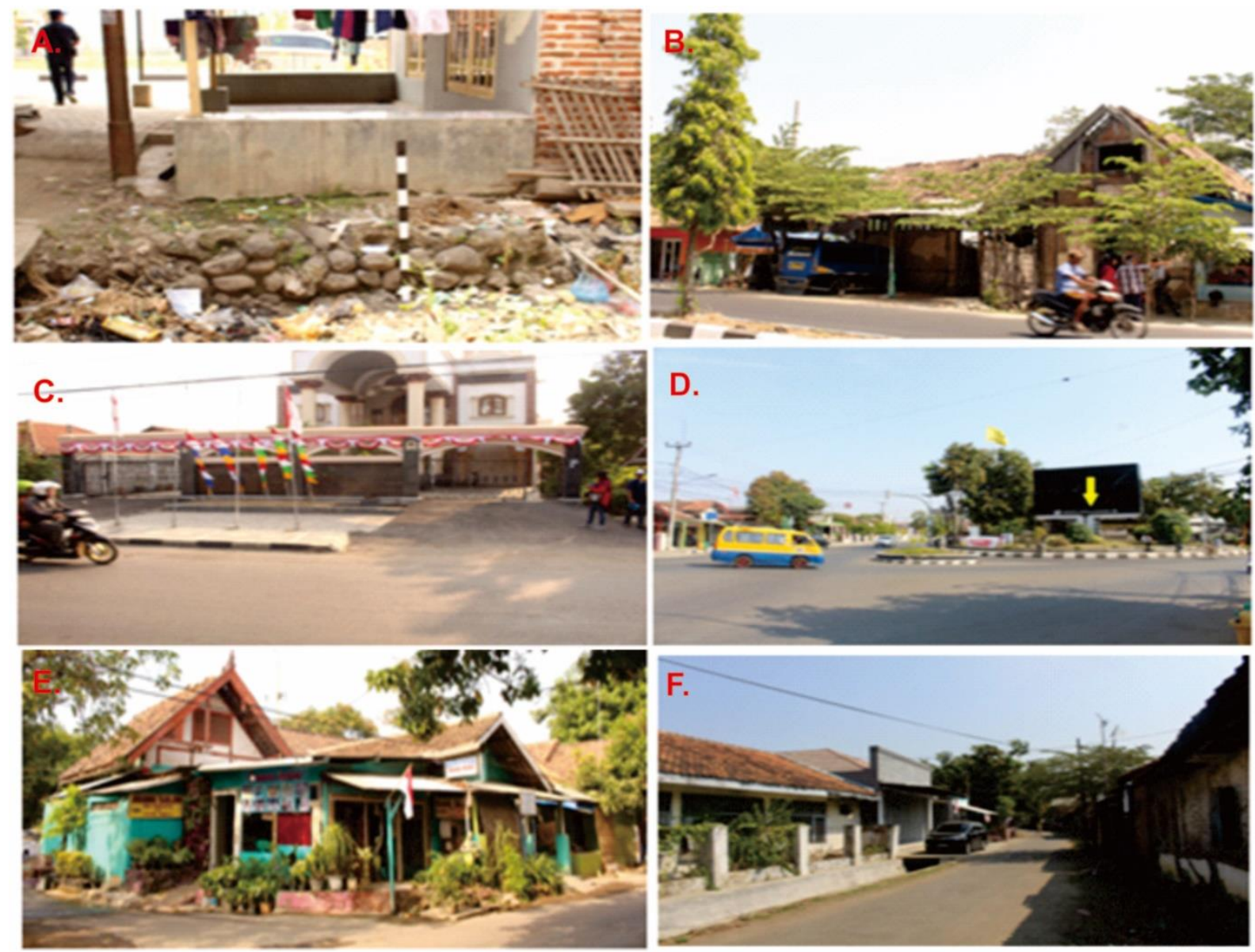

Gambar 2. Struktur bekas Fondasi Stopplaats Pawidean (A). Bangunan bekas Halte Lobener yang sudah beralih fungsi (B). Lokasi Stopplaats Cimanuk (C). Lokasi Stopplaats Karangturi ditunjukan oleh tanda panah (D). Bekas Stasiun Indramayu di Paoman (E). Jalan Kalantahu, bekas jalur kereta api ke Stasiun dari Karangturi (F) (Sumber: Balai Arkeologi Jawa Barat, Tahun 2018).

ini dibangun SS bersamaan dengan jalur KA Cikampek - Cirebon dan beroperasi pada tahun 1912. Operasional Kereta Api dihentikan pada tahun 1970-an akibat kalah bersaing dengan angkutan darat lainnya.

Pada masa aktifnya, kereta di jalur ini melewati 10 perhentian, yaitu Jatibarang, Pawidean, Kalikrasak, Lobener, Karangsembung, Pekandangan, Cimanuk, Cimanukpasar, Karangturi, dan Indramayu (Paoman). Sebagian besar perhentian tersebut merupakan perhentian yang tidak tetap atau kereta akan berhenti jika ada permintaan.

Perjalanan kereta api dari Jatibarang ke Indramayu ditempuh selama 50 menit dan akan selalu berhenti di Perhentian:
Jatibarang, Pawidean, Lobener, Cimanuk, dan Indramayu. Stasiun Pawidean merupakan perhentian dengan kelas Stopplaats. Stasiun ini pada masa aktifnya merupakan perhentian pertama arah Indramayu dari Stasiun Jatibarang.

Saat ini, bangunan Perhentian (Stopplaats) Pawidean sudah tidak ada dan tersisa adalah struktur fondasi sisi barat bangunan berupa susunan batu alam (gambar 2A). Menurut keterangan Samsudin (71 tahun), Pensiunan Pegawai PTKAI bagian Jalan Jembatan wilayah Jatibarang, Jalur kereta api menuju Indramayu berada di sisi barat sejajar dengan Jalan Raya Jatibarang - Indramayu dan bangunan perhentiannya berada di sisi barat Jalan 
kereta api. Stopplaats Pawidean merupakan perhentian yang tidak dilayani dan hanya memiliki satu jalur utama sehingga tidak melayani persilangan kereta api.

Perhentian selanjutnya adalah perhentian Lobener atau dikenal juga dengan sebutan Halte Tegalagung adalah perhentian Trem dengan kelas Halte, terletak di Desa Tegalagung. Halte Lobener (gambar 2B) merupakan halte yang melayani persilangan, pengisian bahan bakar, dan naik turun penumpang. Perhentian ini merupakan perhentian yang dilayani petugas. Menurut keterangan Samsudin (71 tahun), Pensiunan PT KAI, Emplasemen Stasiun Lobener memiliki 2 sepur yaitu sepur utama dan sepur pembelok. Stasiun Lobener merupakan jenis stasiun Pulau, yaitu bangunan stasiun berada di antara dua sepur.

Kemudian Perhentian Cimanuk sebagai perhentian dengan kelas Stopplast (gambar 2C). Perhentian ini berlokasi di Jalan Kembar, Kepandean Blok Cimanuk Kecamatan Karangturi Kabupaten Indramayu. Berdasarkan Grondkaart SS milik PT. Kereta Api Indonesia, Perhentian Cimanuk merupakan perhentian yang hanya melayani naik turun penumpang. Pada Grondkaart digambarkan bahwa dari titik perhentian Cimanuk terdapat persimpangan menuju DAM Cimanuk, bekas jalur tersebut sekarang menjadi jalan menuju DAM Cimanuk.

Saat ini, perhentian Cimanuk sudah tidak ada yang tersisa, bangunan perhentian sudah rata dengan tanah dan beralih fungsi menjadi bagian dari trotoar jalan. Demikian pula dengan jalan rel yang membentang dari Lobener ke Karangturi sudah tidak ada beralih fungsi menjadi bagian jalan raya akibat pelebaran jalan raya Jatibarang Indramayu (jalan kembar).

Berikutnya adalah Perhentian Karangturi (gambar 2D), yang merupakan perhentian dengan kelas Stopplast, terletak di Jalan Yos Sudarso tepatnya di simpang empat (bundaran) Adipura.
Perhentian terakhir di lintas Jatibarang - Indramayu, adalah Stasiun Indramayu di daerah Paoman, tidak jauh dari Dermaga Ci Manuk. Sebagai perhentian terakhir, berbagai fasilitas perkeretaapian dibangun untuk melayani perjalanan kereta api dari Indramayu ke Jatibarang.

Penghapusan perjalanan kereta api lintas Jatibarang - Indramayu pada tahun 1970-an berakibat pada keberadaan berbagai fasilitas perkeretaapian yang dibangun menjadi terbengkalai dan akhirnya rusak/hancur. Tinggalan berupa fasilitas perkeretaapian di kawasan Paoman, adalah emplasemen stasiun, jalur rel, bangunan stasiun, bangunan rumah dinas Kepala Stasiun, gudang, tempat pengisian air.

Perhentian trakhir dari jalur ini adalah Halte Indramayu yang memiliki emplasemen yang lebih luas dibanding dengan perhentian lainnya antara Jatibarang - Indramayu. Fasilitas perkeretaapian di Stasiun Indramayu meliputi gudang, rumah dinas, pengisian air dan kayu bakar, serta peron. Saat ini, peron Stasiun Indramayu sudah tidak ada. Struktur fondasi peron masih dapat diamati di lahan kosong seberang bangunan stasiun (gambar 2E).

Railbed di kawasan Stasiun Indramayu saat ini difungsikan sebagai jalan yang memanjang dari Kalantahu sampai stasiun Indramayu (gambar 2F). Berdasarkan grondkaart SS, jalur kereta api tersebut melewati stasiun terus ke arah Barat berakhir di tepi Ci Manuk (Jalan Siliwangi). Seiring dengan ditutupnya layanan kereta api pada jalur Jatibarang - Indramayu, stasiun Indramayu dan stasiun lainnya di jalur tersebut ikut ditutup karena tidak lagi melayani perjalanan kereta api. Saat ini, bangunan bekas Stasiun Indramayu beralih fungsi menjadi tempat tinggal tiga keluarga yang merupakan anak-anak dari mantan Pegawai PJKA, yaitu Jayono, Castiti, dan Kuni. 


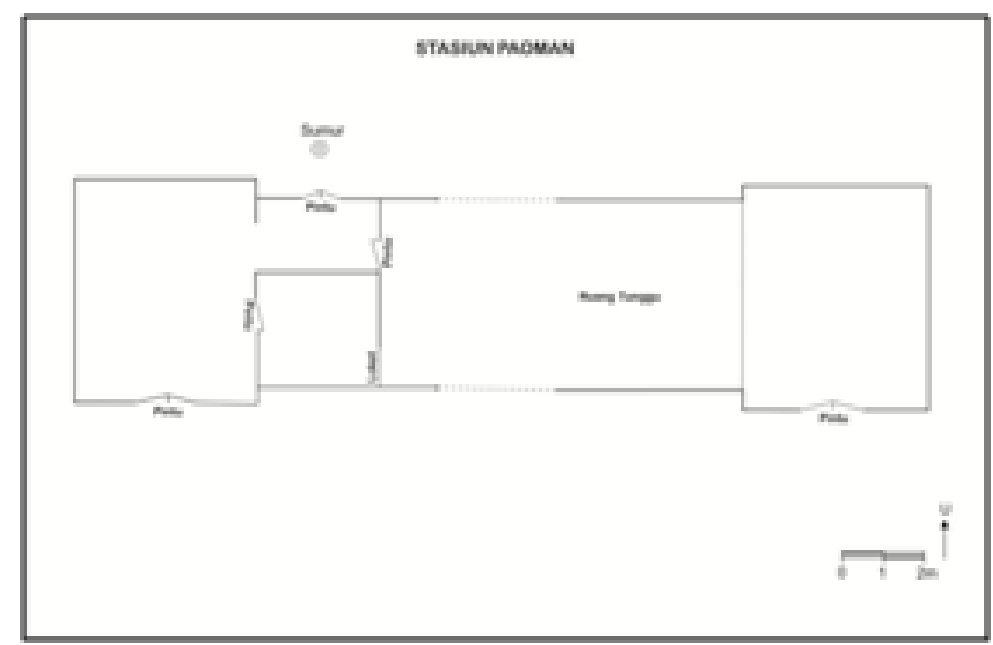

Gambar 3. Denah bekas Stasiun Indramayu di Paoman (Sumber: Balai Arkeologi Jawa Barat, Tahun 2018)

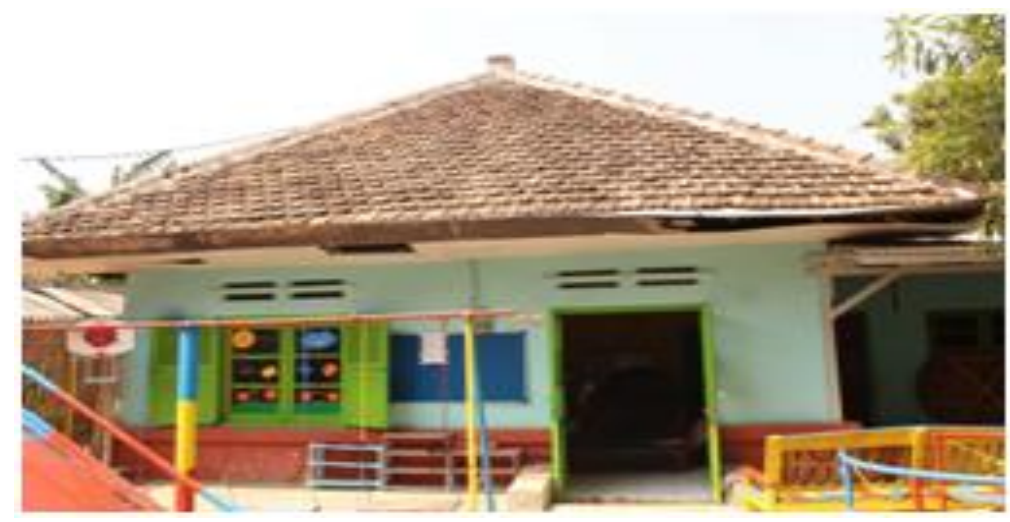

Gambar 4. Bekas rumah dinas dalam jabatan Stasiun Indramayu di Paoman yang sudah beralih fungsi (Sumber: Balai Arkeologi Jawa Barat, Tahun 2018)

Denah bangunan stasiun persegi panjang dengan bentuk simetris membujur Barat Timur dengan arah harap Utara Selatan (gambar 3). Bangunan dilengkapi dengan dua menara dan dua gable dengan material kayu pada gable sebagai ornamen dan konsol geometris. Bangunan telah mengalami perubahan pada tata ruang, penambahan sekat, dan dinding.

Komponen bangunan yang sudah berubah antara lain mayoritas lantai dan penggantian beberapa genting. Komponen asli ditemukan pada sebagian jendela dan pintu. Penambahan terjadi pada ruang bagian barat, yaitu ditambah area kamar mandi di dalam bangunan stasiun. Fasade bangunan secara keseluruhan tidak dapat terlihat dengan jelas karena adanya bangunan baru di sisi utara dan selatan bangunan. Pada jalur ini juga dlengkapi dengan fasilitas penunjang berupa rumah dinas (gambar 4), bedeng pegawai dan gudang.

\section{Tinggalan Perkeretaapian di Pusat Aktivitas Ekonomi Cimanuk.}

Bandar Cimanuk adalah salah satu pusat aktifitas ekonomi Indramayu pada masa kolonial Belanda. Berbagai bangunan penunjang aktivitas perekonomian dan pemerintahan dibangun di kawasan ini. Beberapa tinggalan terkait perkeretaapian di kawasan ini diantaranya bangunan rumah 


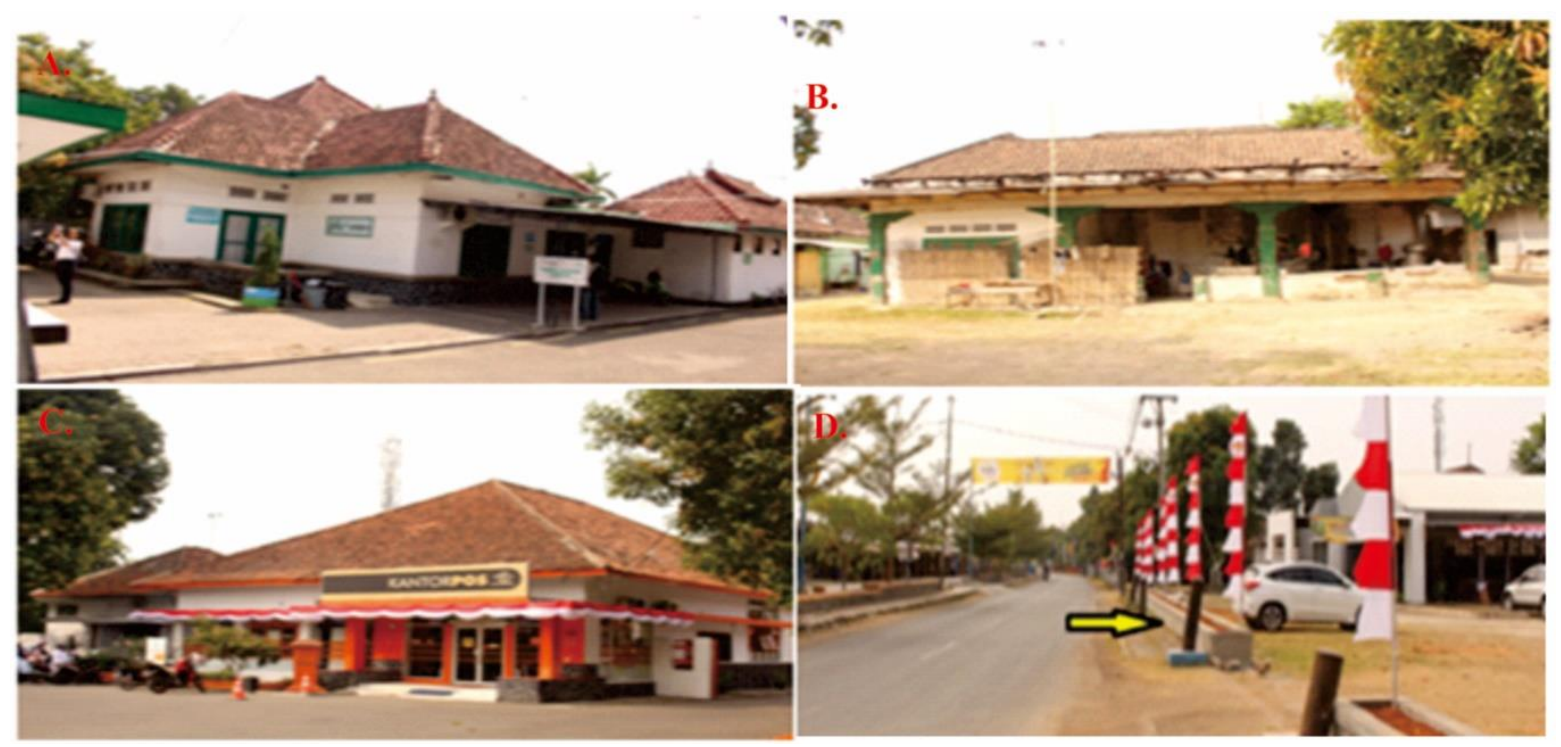

Gambar 5. Bekas Kantor Administrator yang telah berubah fungsi menjadi kantor PLN (A). Bangunan Penggilingan Padi (B). Kantor pos dengan bangunan peninggalan masa Kolonial Belanda (C). Bollard/Boller (tiang pengikat kapal) peninggalan masa Kolonial Belanda (D) (Sumber: Balai Arkeologi Jawa Barat, Tahun 2018)

lama, bekas kantor administrator yang kini difungsikan sebagai kantor PLN (gambar $5 \mathrm{~A}$ ), bekas penggilingan padi saat masa tanam paksa (gambar 5B), kantor pos masa kolonial (gambar 5C), tiang pengikat kapal masa pemerintah kolonial (gambar 5D), bekas rumah asisten residen dan gudang garam.

\section{Tinggalan Perkeretaapian di Jalur Jatibarang-Karangampel.}

Jalur Kereta Api Jatibarang Karangampel adalah jalur cabang dari Jatibarang menuju Karangampel sepanjang $19 \mathrm{~km}$. Jalur ini merupakan jalur Trem yang dibuka pada tahun 1926 dan pada tahun 1930-an ditutup. Sebagaimana ekspansi ke Indramayu, maksud pembukaan jalur trem ke Karangampel tujuan utamanya adalah untuk mengakut hasil pertanian, terutama padi. Pada jalur kereta api Jatibarang Karangampel saat ini sudah tidak terlihat petunjuk pernah beroperasinya kereta api.

Jejak-jejaknya sudah hilang dan hanya menjadi memori turun temurun sebagian warga setempat. Berdasarkan informasi yang diperoleh dari Grondkaart dan informasi lisan dari warga, beberapa titik masih dapat dikenali sebagai jejak arkeologis perkeretaapian di jalur Jatibarang - Karangampel.

Saat ini bangunan Halte sudah tidak ada, di bekas bangunan perhentian sekarang difungsikan sebagai taman kota (gambar 6A). Menurut cerita, ketika kereta api masih beroperasi (tahun 1970-an) pernah terjadi kecelakaan dimana Bis Hiba yang melaju di Jalan Raya Lohbener - Cirebon menabrak kereta api yang sedang melintas.

Stasiun Majasih, merupakan perhentian pertama setelah Jatibarang arah ke Karangampel. Kondisi saat ini, bangunan perhentian Majasih sudah tidak ada dan di atas lahan bekas bangunan stasiun berdiri bangunan rumah permanen.

Struktur Jembatan Majasari, merupakan sisa jembatan kereta api di atas saluran Irigasi Majasari, di dekat Stasiun Majasih. Sisa jembatan kereta api di Majasari ini, adalah struktur fondasi abutmen jembatan sisi barat, sedang abutmen Timur sudah tidak ada.

Perhentian Gadingan berada di desa Gadingan kecamatan Gadingan, saat ini 


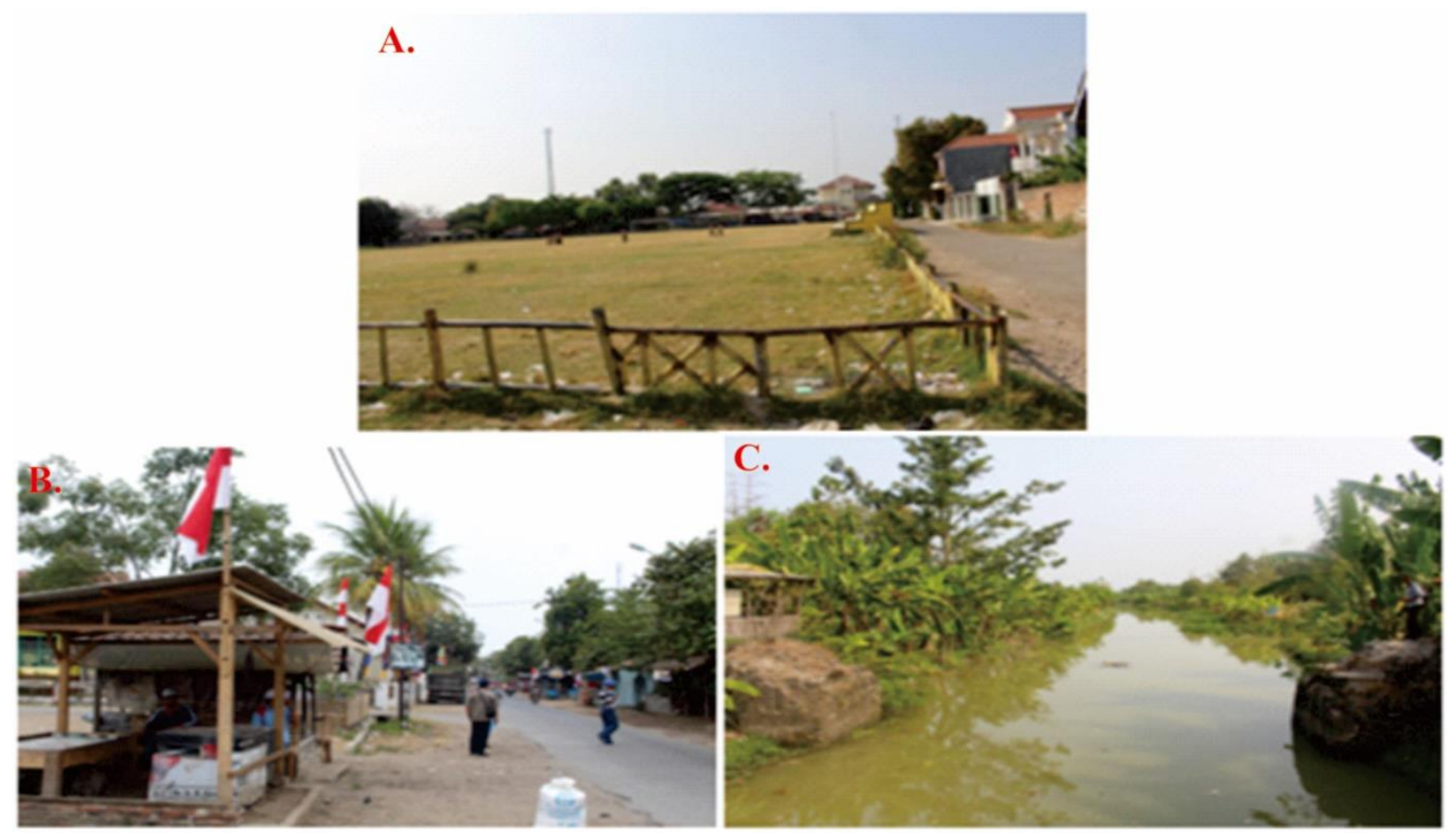

Gambar 6. Bekas Emplasemen Karangampel (A). Bekas jalur kereta api di Gadingan (B). Struktur Abutmen Jembatan Kemujing I (Sumber: Balai Arkeologi Jawa Barat, Tahun 2018).

bekas emplasemen stasiun Gadingan difungsikan sebagai lapangan Gadingan (gambar 6B). Menurut pengakuan Ibu Tarisem (87 tahun), “pada saat masih muda dirinya sering berjalan kaki menyusuri rel dari Gadingan ke Majasari untuk berjualan, demikian juga rekan-rekannya yang akan berjalan kaki menyusuri jalur kereta bila mau ke tempat lain, bahkan ke Jatibarang atau Karangampel".

Berkenaan dengan keberadaan angkutan kereta api dari Jatibarang ke Karangampel, sepengetahuan beliau sejak kecil sudah tidak melihatnya lagi, hanya relnya yang memanjang di tengah-tengah sawah. Keberadaan kereta api hanya didengarnya dari cerita orang tua dan tetangga yang sudah sepuh.

Struktur fondasi Jembatan Kemujing merupakan struktur jembatan kereta api yang berada pada ruas Jatibarang Karangampel (gambar 6C). Berdasarkan struktur jembatan yang tersisa, pada bagian bawah jembatan menyerupai terowongan. Bahan yang dipergunakan dalam membangun jembatan ini, adalah batu alam.
Saat ini, struktur bekas jembatan kereta api berada di sebelah selatan jembatan baru yang merupakan jembatan jalan raya. Hal ini menunjukkan bahwa jalur kereta api berada di tepi jalan bagian selatan.

\section{Tinggalan Perkeretaapian Kecamatan Karangampel.}

Karangampel, adalah salah satu kecamatan di Indramayu. Pada masa Kolonial Belanda, Karangampel memiliki nilai strategis secara ekonomi karena pada tahun 1926 Perusahaan Kereta Api milik Pemerintah Kolonial Belanda, SS, membuka rute perjalanan kereta api dari Jatibarang ke Karangampel.

Perjalanan Kereta Api dari Stasiun Jatibarang ke Karangampel memakan waktu 50 menit dan melewati 8 Perhentian, yaitu Jatibarang, Najasih, Sliyeg, Gadingan, Segeran, Jumtikebon, Mundu, dan Karangampel. Stasiun Karangampel sebagai stasiun akhir/tujuan perjalanan kereta api pada ruas Jatibarang-Karangampel memiliki fasilitas penunjang perjalanan kereta api yang lebih lengkap dibanding 
stasiun antara pada ruas Jatibarang Karangampel. Saat ini bangunan stasiun Karangampel sudah tidak ada, bahkan struktur fondasinya juga sudah tidak ditemukan. Lahan emplasemen stasiun sekarang menjadi bagian dari Lapangan Olah Raga.

Jalur rel beralih fungsi menjadi jalan desa, demikian pula dengan jembatan kereta api beralih fungsi menjadi jembatan jalan desa. Berdasarkan grondkaart, stasiun Karangampel memiliki empat Sepur, sebagian dari sepur tersebut mengarah ke pergudangan di emplasemen Karangampel.

Karangampel merupakan salah satu wilayah yang pada masa kolonial Belanda sebagai salah satu wilayah yang ramai (lampiran 3). Catatan Residen Cirebon pada tahun 1930 menunjukkan bahwa Karangampel merupakan salah satu sentra beras di wilayah Karesidenan Cirebon. Pasar Karangampel berdiri tidak jauh dari Stasiun Karangampel, fasilitas perkotaan lainnya yang berdiri tidak jauh dari Stasiun, adalah Pegadaian dan Kantor Pos.

\section{Tinggalan Perkeretaapian Kecamatan Haurgeulis.}

Haurgeulis adalah satu kecamatan di Indramayu, letaknya berbatasan dengan kabupaten Subang. Lokasinya jauh di selatan Jalan Raya Pantura Jawa Barat dan saat ini merupakan salah satu kecamatan yang ramai di wilayah Indramayu. Perhentian Haurgeulis merupakan perhentian yang melayani naik turun penumpang untuk beberapa kereta api arah Jakarta dan Cirebon.

Jejak masa lalu di Haurgeulis, adalah berupa Bangunan Stasiun, Rumah Dinas Jabatan, Tempat Pengumpulan Kayu, Kantor Perhutani, Pabrik Beras, dan Rumah Sakit (lampiran 4). Stasiun Haurgeulis terletak Jalan Cipunagara - Haurgeulis di Kecamatan Haurgeulis. Stasiun Haurgeulis merupakan salah satu stasiun yang melayani perjalanan kereta api di Jalur Utara Pulau Jawa (gambar 7A).
Stasiun ini melayani naik turun penumpang untuk Kereta Bogowonto, Ciremai Ekspres, Gajahwong, Kertajaya, Tawangjaya, Tegal Ekspres, Cirebon Ekspres, Fajar Utama Yogyakarta, Gayabaru, Singasari, dan Tegal Bahari. Bangunan Stasiun berdenah persegi, secara garis bersar terdiri dari tiga bagian yaitu Ruang Perkantoran, Ruang Tunggu (Hall), dan gudang stasiun.

Ruang perkantoran mencakup ruang Kepala Stasiun, Ruang Penjualan Tiket, dan Ruang PPKA (Pengatur Perjalanan Kereta Api). Kondisi saat ini, Ruang Kepala Stasiun terpisah dengan Ruang Penjualan Tiket, karena ruang penjualan tiket berada di bangunan baru yang berbatasan langsung dengan Ruang Tunggu, sedangkan ruang tiket lama dijadikan sebagai ruang usaha (toko Roti). Kelengkapan di ruang penjualan tiket, seperti meja tiket dan brankas tanam sudah tidak ada. Dari Ruang tunggu (Hall), Jendela tiket masih ada dalam kondisi jendela kayu tertutup, sedang di bagian dalam sudah ditutup Wallpaper dan perlengkapan Toko.

Stasiun Haurgeulis dilengkapi dengan Rumah Dinas Jabatan untuk Kepala Stasiun dan pejabat lainnya (gambar 7B), kemudian sekitar 100 meter arah timur dari bangunan stasiun Haurgeulis terdapat lahan terbuka yang ditanami pohon Mahoni, serta di sela-sela pepohonan tesebut dipenuhi oleh rumput dan tumbuhan perdu. Menurut keterangan Sumadi, Staf bagian asset PT. KAI Daop 3 Cirebon, lahan tersebut sebelumnya adalah lahan tempat penampungan kayu yang dibawa dari kehutanan di bagian selatan dengan menggunakan lori (Decauville).

Keterangan tersebut diperkuat oleh Fauzi (kepala Stasiun Haurgeulis). Menurut Nasim, staf BPKH Haurgeulis, menjelaskan bahwa terdapat jalur cabang khusus dari Stasiun Haurgeulis ke Tempat Penampungan Kayu (TPK) Haurgeulis untuk bongkar muat di gudang kayu. Kayukayu tersebut berasal dari kehutanan di 

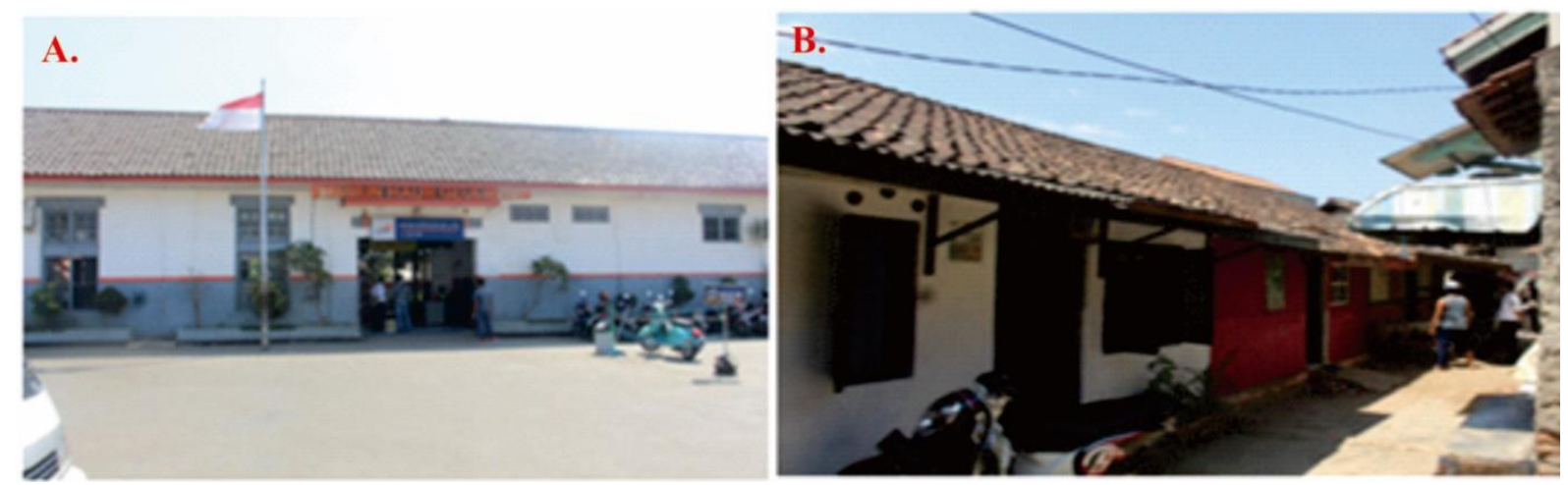

Gambar 7. Stasiun Haurgeulis (A). Bedeng pekerja Stasiun Haurgeulis pemerintah masa colonial (B). (Sumber: Balai Arkeologi Jawa Barat, Tahun 2018)

wilayah Subang dan Sumedang yang diangkut dengan menggunakan lori ke TPK. Stasiun Haurgeulis juga dilengkapi dengan Rumah Dinas Sinder berarsitektur masa kolonial Belanda, terdapat tempat penggilingan padi dan fasilitas rumah sakit pegawai.

\section{Tinggalan Perkeretaapian di Sekitar Stasiun Kadokangabus dan Fasilitas Penunjangnya.}

Stasiun Kadokangabus (Kab) adalah salah satu Stasiun aktif di lintas Cikampek Cirebon, tepatnya di antara Stasiun Cilegeh (Clh) dan Stasiun Terisi (Tis). Stasiun ini terletak di Desa Kadokangabus, Kecamatan Gabuswetan, Kabupaten Indramayu, pada koordinat 1080 06' 22.62" BT dan 060 28' 04.01" LS. Stasiun ini merupakan stasiun kelas 3 yang melayani perjalanan kereta api namun tidak melayani naik turun penumpang dan barang. Sejak diberlakukannya jalur ganda Jakarta Surabaya, kereta api tidak berhenti di stasiun ini kecuali dalam kondisi yang mengharuskannya berhenti.

Sebelum dibangun Rel Ganda Jakarta - Surabaya, berdasarkan buku Ikhtisar Lintas dan Emplasemen Wilayah Jawa, Stasiun Kadokangabus (Kab) miliki 1 sepur lurus, 2 sepur pembelok dan 1 sepur badug. Stasiun ini juga dilengkapi dengan Gudang Barang, dan tempat bongkar muat tinggi. Saat ini, Stasiun Kadokangabus
(Kab) mempunyai 4 Jalur sepur, sepur 2 dan 3 merupakan sepur lurus (sepur utama), sedangkan sepur 1 dan 4 merupakan sepur pembelok. Stasiun ini merupakan Stasiun Pulau, karena sepur 1 di belakang bangunan stasiun sehingga bangunan stasiunnya diapit oleh jalan kereta api. Tinggalan arkeologis di Stasiun Kadokangabus (Kad), adalah Bangunan Stasiun, bangunan gudang, toilet dan peralatan penunjang perjalanan kereta api.

\section{Tinggalan Perkeretaapian di Sekitar Stasiun Terisi dan Fasilitas Penunjangnya.}

Terisi adalah salah satu Stasiun di Jalur aktif Jakarta - Cirebon, berlokasi di Kecamatan Terisi Kabupaten Indramayu pada koordinat $108^{0} 09^{\prime} 39.21^{\prime \prime}$ BT dan $06^{0}$ 28' 11.32" LS. Saat ini, stasiun terisi merupakan stasiun yang tidak aktif melayani naik turun penumpang. Stasiun ini hanya melayani perjalanan kereta api. Bangunan stasiun berdenah persegi yang dibagi pada tiga bagian ruang, yaitu Ruang tunggu (Hall), Ruang Kepala Stasiun dan Ruang Penjualan Tiket, serta Ruang PPKA.

\section{Tinggalan Perkeretaapian di Sekitar Stasiun Telagasari dan Fasilitas Penunjangnya.}

Stasiun Telagasri berada di Desa Telagasari, Kecamatan Lelea Indramayu. Stasiun Telagasari merupakan stasiun kelas 


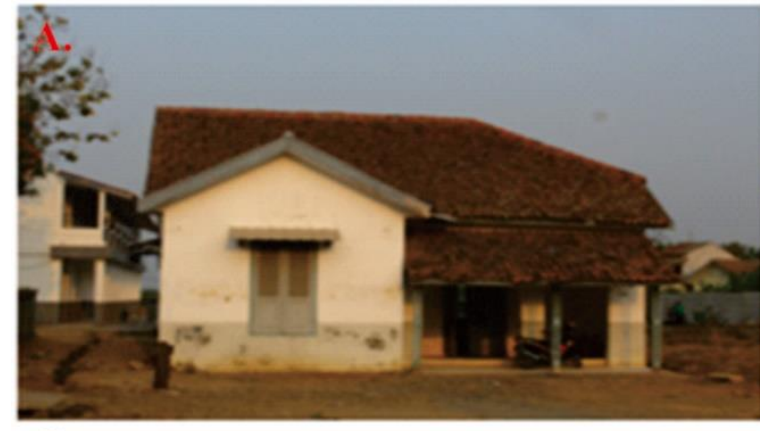

C.

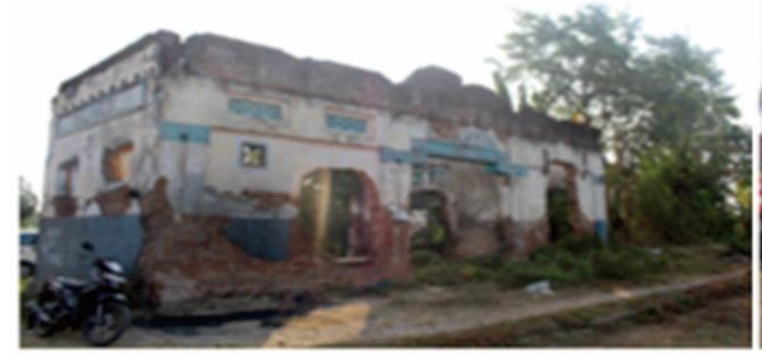

B.

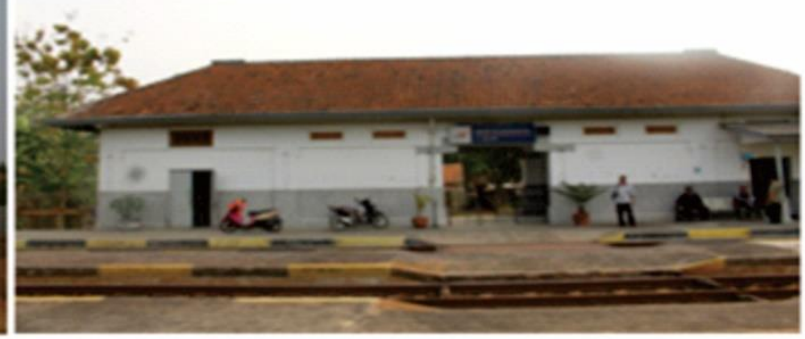

D.

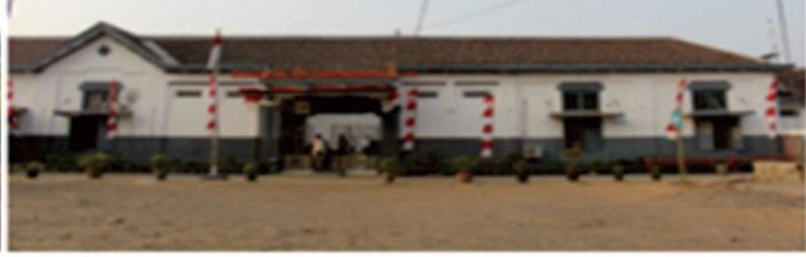

Gambar 8. Bangunan Stasiun Jatibarang peninggalan masa colonial (A). Bangunan Stasiun Kertasemaya peninggalan masa colonial (B). Bangunan Stasiun Kaliwedi peninggalan masa kolonial (C). Bangunan Rumah Dinas di Arjawinangun peninggalan masa kolonial (D) (Sumber: Balai Arkeologi Jawa Barat, 2018)

3 di Jalur kereta api Cikampek - Cirebon. Saat ini, Stasiun Telagasari hanya melayani perjalanan kereta api dan tidak melayani naik turun penumpang.

Sejak dibangunnya jalur rel ganda Jakarta - Surabaya, jumlah sepur di stasiu Telaga sari menjadi 4 sepur dengan sepur 2 dan sepur 3 sebagai sepur lurus. Sebelum dibangun jalur rel ganda, Stasiun Telagasari memiliki 3 sepur dan 1 sepur badug dengan sepur 2 sebagai sepur lurus, serta memiliki fasilitas untuk bongkar muat hewan.

\section{Tinggalan Perkeretaapian di Jalur Jatibarang-Arjawinangun.}

Jatibarang (gambar 8A) dan Arjawinangun adalah stasiun besar yang ada di wilayah kerja PT. KAI Daerah Operasional 3 Cirebon dan melayani naik turun penumpang dan barang selain melayani lalu lintas perjalanan kereta api. Antara Jatibarang sampai Arjawinangun terdapat satu stasiun kelas 3 yang hanya melayani perjalanan kereta api dan tidak melayani naik turun penumpang, yaitu Kertasemaya (gambar 8B). Sebelum ditutup, sebelum mencapai Stasiun Arjawinangun akan melewati Stasiun Kaliwedi (gambar $8 \mathrm{C})$.

Berdasarkan Memori Serah Jabatan Residen Cirebon, C.J.A.E.T. Hiljee, tanggal 3 Juni 1930, Stasiun Kertasemaya (Bangodua), Kaliwedi, dan Arjawinangun (gambar 8D) lebih berfungsi sebagai stasiun pengirim komoditas pertanian dibanding sebagai stasiun penerima. Semua hasil pertanian berupa beras, kentang, kacang tanah, sayuran, dan buah-buahan dikirim ke luar Karesidenan Cirebon.

\section{PENUTUP}

Kedudukan pemerintah Kolonial Belanda selalu terkait dengan eksplorasi dan eksploitasi komoditas pertanian di Indonesia. Kegiatan tersebut harus didukung oleh sarana transportasi yang memadai untuk mengangkut hasil komoditas yang dieksploitasi. Salah satu mode transportasi yang digunakan khususnya erat dengan keberadaan politik tanam paksa adalah mode transportasi kereta api.

Indramayu adalah salah satu wilayah yang dilalui oleh jalur pembangunan mode 
transportasi tersebut, terdapat tiga jalur yang melaluinya yakni (1) Jalur kereta api non aktif Jatibarang - Indramayu; (2) Jalur kereta api non aktif Jatibarang Karangampel; (3) Jalur Haurgeulis Arjawinangun. Terdapat tinggalan perkeretaapian di beberapa kecamatan dan hasil penelusuran setiap jalurnya baik berupa bangunan, jejak rel dan faslilitas penunjang lainnya bergaya masa kolonial belanda.

Jalur kereta api tersebut, dikembangkan untuk kepentingan eksplorasi dan eksploitasi sumberdaya alam, khususnya komoditas pertanian yang digunakan untuk bahan primer industri, khususnya Industri Gula dan komoditas pertanian tanaman pangan. Ini terlihat dari tinggalan perkretaapian yang berkorelasi dengan keberadaan beberapa pabrik gula di sekitar Wilayah Indramayu dan kantor administrasi tanaman pangan khususnya padi. Wilayah indramayu menjadi salah satu pemasok bahan pangan dan tebu untuk pabrik gula. Pembangunan dilakukan seiring dengan perluasan wilayah kekuasaan eksplorasi pemerintah Kolonial Belanda khususnya gencar saat diberlakukannya politik tanam paksa oleh pemerintah kolonial

Tinggalan tersebut seharusnya dijaga dan dilestarikan oleh instansi tekait sebagai aset peninggalan sejarah yang memiliki nilai arkeologis sebagai saksi sejarah bagaimana perkembangan mode transportasi, kehidupan dan eksploitasi pemerintah kolonial di Indonesia.

\section{Ucapan Terima Kasih}

Tulisan ini tidak akan bisa diselesaikan tanpa dukungan dan bantuan dari Semua pihak, terutama di saat pengumpulan data lapangan samapi analisis data. Ijinkan pada kesempatan ini kami mengucapkan terima kasih yang sebesar-besarnya kepada Semua Anggota Tim Peneitian Arkeologi di Wilayah Cirebon Timur dan Indramayu, terutama kepada Oerip Bramantyo Boedi, Effie Latifundia, Acep, Irawan, Sukirdja, Upik Listyorini, dan Ibnu Fauzan. Kami juga ucapkan terima kasih kepada Jajaran PT. Kereta Api Indonesia DAOP 3 Cirebon yang telah memberi izin penelitian dan pendampingan selama pengumpulan data lapangan. Mustaqim Astedja, Nang Sadewo, Sumadi dan pihak-pihak lainnya yang tidak bisa disebut satu persatu yang telah membantu selama kegiatan pengumpulan data lapangan dan memberikan informasi berkenaan dengan tinggalan Perkeretaapian di Wilayah Cirebon.

\section{DAFTAR PUSTAKA}

Anwar, S. (2017). Keruangan Perkotaan Medan dalam Tinjauan Transportasi Perkotaan Masa Kolonial. Jurnal Sejarah Peradaban Islam, 1(2), 341-351.

Balan, C., \& Ionita, C. (2011). Exploratory Research On The Organizational Learning In Small Enterprises And Implications For The Economic Higher Education. Amfiteatru Economic Journal, 13(30), 463-481.

BPS. (2015). Indramayu dalam Angka 2015. Indramayu: Badan Pusat Statistik Kabupaten Indramayu.

Hendro, E. P. (2014). Perkembangan Morfologi Kota Cirebon dari Masa Kerajaan hingga Masa Akhir Kolonial. Jurnal Paramita, 24(1), 18.27. 
Makkelo, I. D. (2017). Sejarah Perkotaan: Sebuah Tinjauan Historiografis dan Tematis. Lensa Budaya, 12(2), 83-101.

Mudjianto, B. (2018). Tipe Penelitian Eksploratif Komunikasi. Jurnal Studi Komunikasi Dan Media, $22(1), 65-74$.

Pratikto, D. (2018). Penelusuran Bentuk Arsitektur Bangunan Stasiun Kereta Api Jaman Kolonial Di Yogjakarta. Jurnal Teknik Sipil Dan Arsitektur, 22(26), 1-13.

Pribadi, S. (2012). Perkembangan Infrastruktur Kereta Api Tahun 1950 - 1970. Jurnal Verleden, 1(1), 73-85.

Purwanto, E. (2008). Kajian Arsitektural Stasiun Nis. Jurnal Ilmiah Perancangan Kota Dan Permukiman, 7(2), 98-105.

Ramadhan, A. P. (2017). Pengaruh Jalur Kereta Api Batavia-Buitenzorg Terhadap Kehidupan Sosial dan Ekonomi Masyarakat Batavia Tahun 1875-1913. E-Journal Universitas Negeri Yogyakarta, $1-12$.

Reiter, B. (2017). Theory and Methodology of Exploratory Social Science Research. IJRSM Journal, $5(4), 130-150$. 


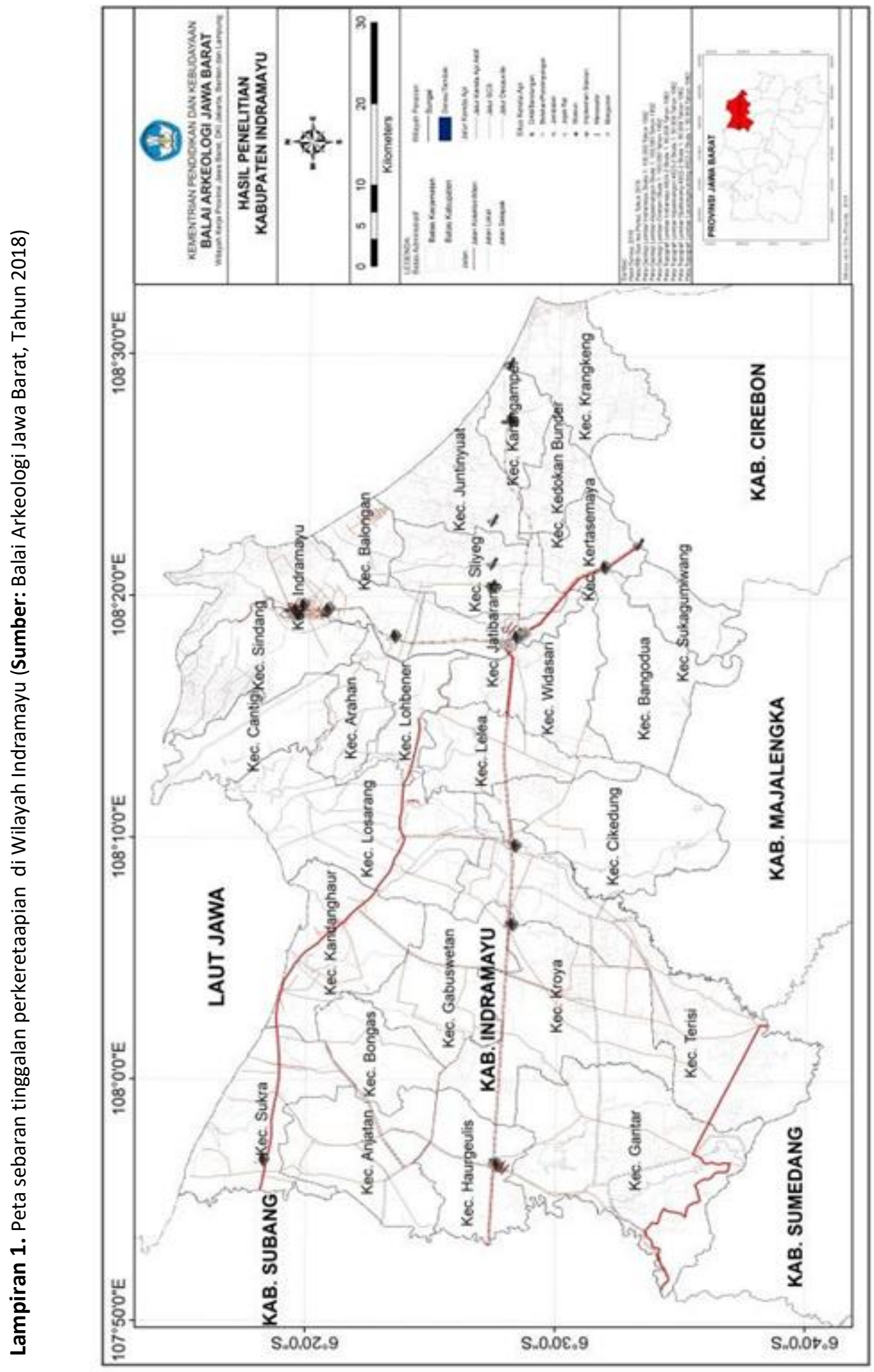




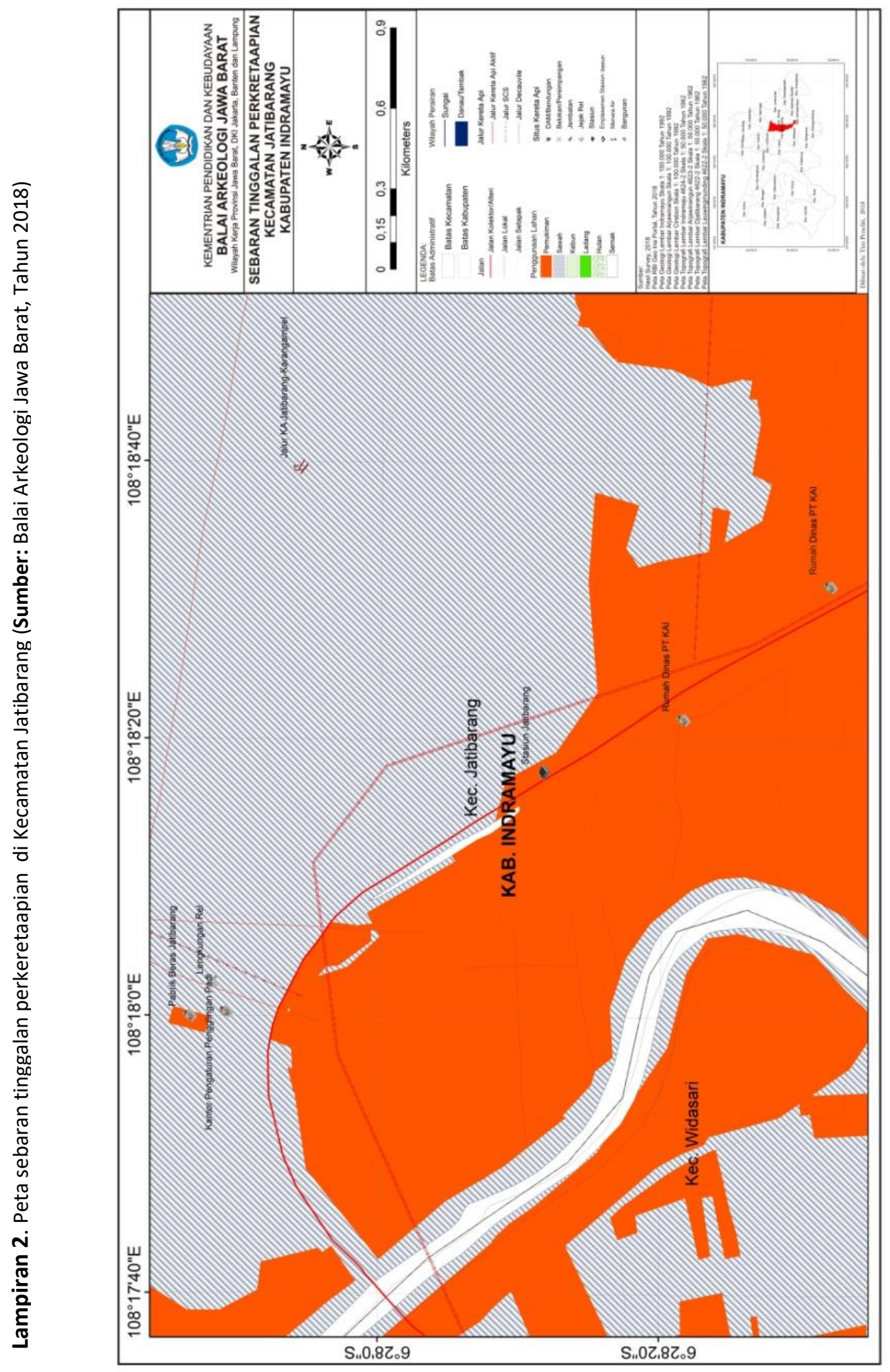

Jurnal Walennae, Vol. 17, No. 2, November 2019: Hal. 125-142|141 
Lampiran 3. Peta sebaran tinggalan perkeretaapian di Kecamatan Karangampel (Sumber: Balai Arkeologi Jawa Barat, Tahun 2018)

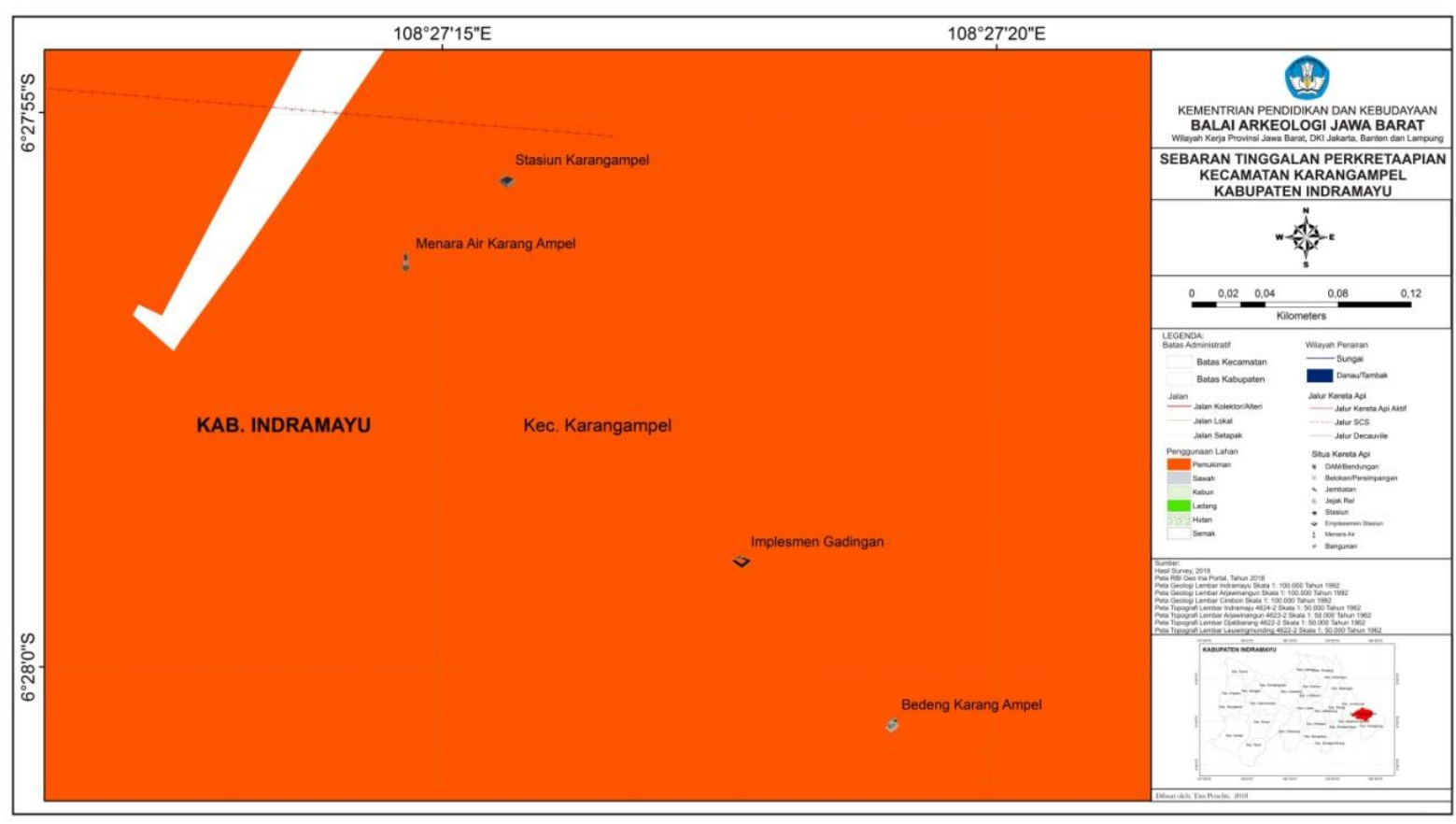

Lampiran 4. Peta sebaran tinggalan perkeretaapian di Kecamatan Haurgeulis (Sumber: Balai Arkeologi Jawa Barat, Tahun 2018)

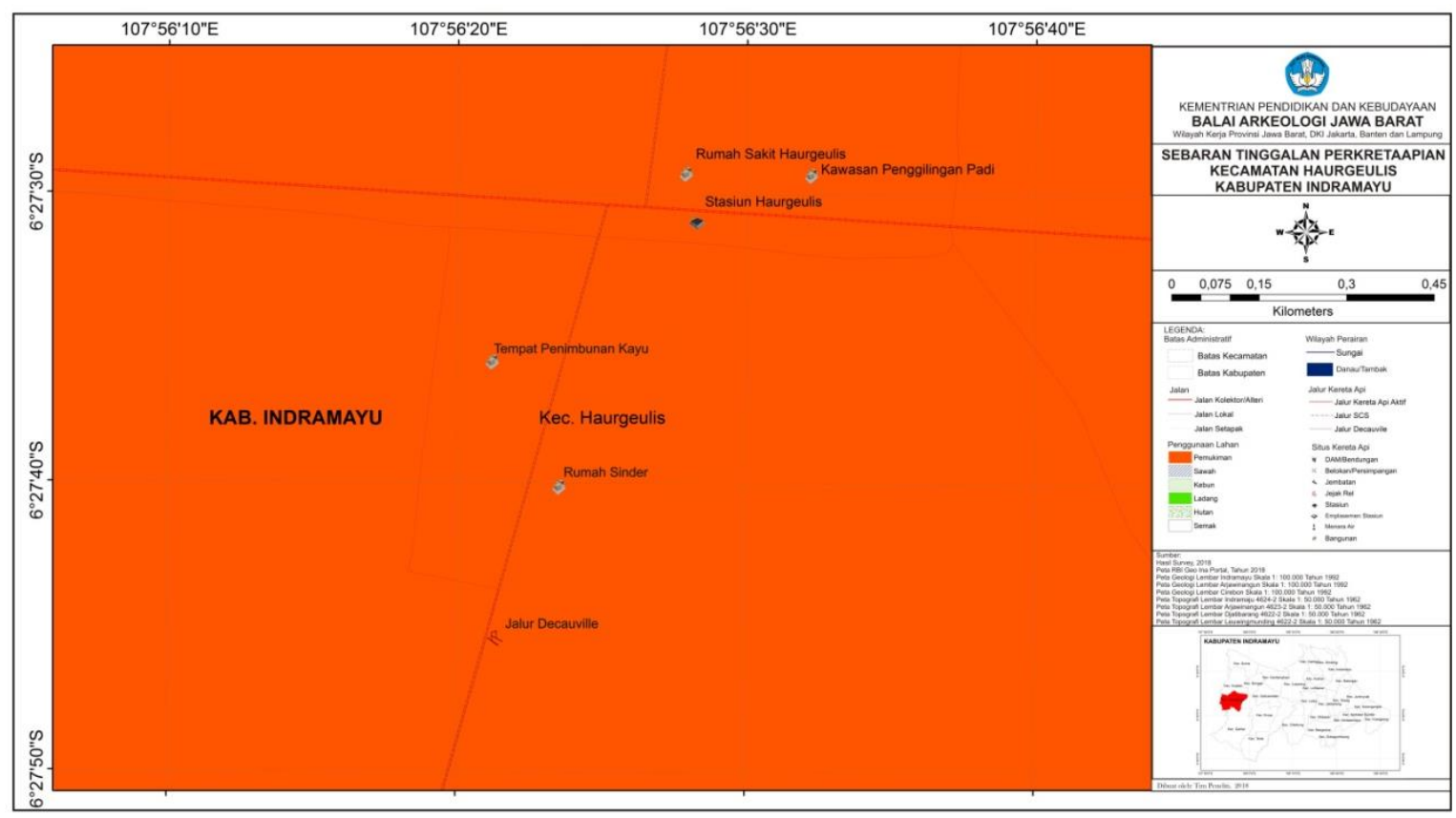

